V. 13 N. 1

JAN-ABR 2017

ISSN 2317-6172

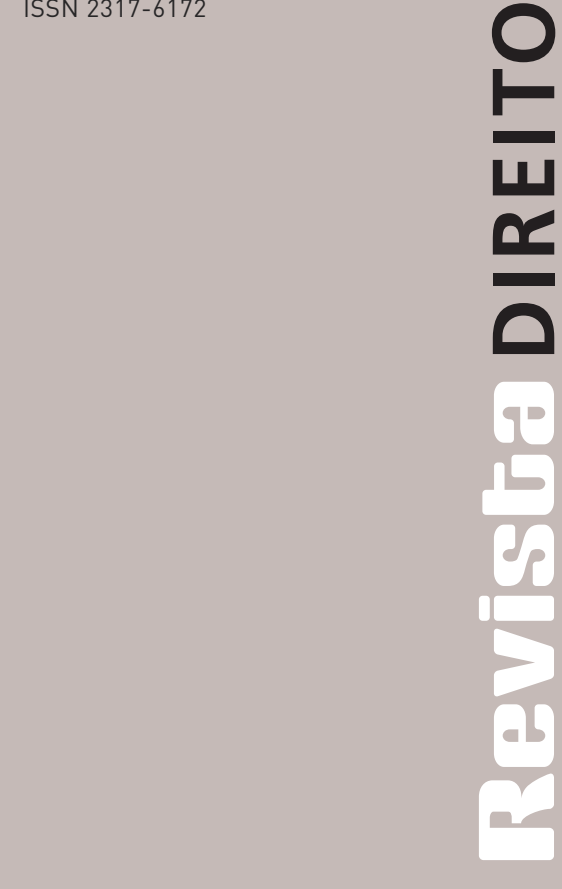

Received: 02.06.2015

Approved: 02.02.2017

DOI: http://dx.doi.org/10.1590/2317-6172201705

1 Federal University of Recôncavo da Bahia Cruz das Almas - BA - Brazil

2 Goiás Court of Justice Corumbaíba - GO - Brazil

3 Sao Paulo State University (UNESP) Tupã - SP - Brazil

\section{Contract farming in Brazil - an approach to Law and Economics}

CONTRATO AGROINDUSTRIAL NO BRASIL - UMA ABORDAGEM DO DIREITO E ECONOMIA

\author{
Kassia Watanabe ${ }^{1}$, Nunziata Stefania Paiva ${ }^{2}$ \\ e Ana Elisa Bressan Smith Lourenzani ${ }^{3}$
}

\begin{abstract}
Contract farming is based on agreements settled prior to the farmer deciding about agricultural production, and influence their judgment regarding inputs and production systems. Therefore, they provide means of production coordination and safety for both farmer and agro-industry/distributor. However, contract farming has its gaps since it is written in abscence of complete information, due to the behavioral assumption of bounded rationality of economic agents. A specific law might generate legal certainty for economic agents, insofar as the Judiciary fulfills the contractual gaps. From the other side, private agents may also fulfill the contractual gaps. As an effort to understand the role of institutions in contract farming, this study aims to analyze the Bill 6,459/2013, which intends to rule contract farming and takes private instituctions into account, through the agency of the Monitoring, Development and Reconciliation of Integration Committee (Cadec). This is an applied research with qualitative approach. The research concludes that the approval of bill might lead to effective typical law for contract farming, provided that the creation of Cadec is encouraged.
\end{abstract}

\section{Keywords}

Contract farming; Bill 6,459/2013; public and private institutions; institutional arrangement; transaction costs.

\section{Resumo}

Os contratos agroindustrais são baseados em acordos feitos antes da produção agropecuária e influenciam as decisões dos produtores quantos aos recursos utilizados e sistemas produtivos adotados. No entanto, os contratos agroindustriais possuem lacunas uma vez que são elaborados sob a condição de informações incompletas devido ao pressuposto comportamental de racionalidade limitada dos agentes econômicos. Uma lei específica pode gerar a segurança jurídica para os agentes econômicos na medida em que o Poder Judiciário preencha as lacunas contratuais. Por outro lado, os agentes privados também podem preencher as lacunas contratuais. Buscando compreender o papel das instituições nos contratos agroindustriais, esse estudo tem como objetivo analisar o Projeto de Lei (PL) $n^{\circ}$ 6.459/2013, que disciplina sobre contrato agroindustrial e leva em conta as instituições privadas, por meio da criação da Comissão de Acompanhamento, Desenvolvimento e Conciliação da Integração (Cadec). Trata-se de uma pesquisa aplicada com abordagem qualitativa. A pesquisa conclui que o PL aprovado pode levar à eficácia da lei típica para o contrato agroindustrial se houver incentivo para a formação do Cadec.

\section{Palavras-chave}

Contrato agroindustrial; Projeto de Lei nº 6.459/2013; instituições públicas e privadas; arranjo institucional; custos de transação. 


\section{INTRODUCTION}

Contract farming generally refers to a form of governance adopted by the agribusiness supply chain to ensure access to agricultural products within certain specifications, such as quality, quantity, origin, and among others (SILVA, 2005). In agribusiness, producers and agro-industries perform a contract that is essential to establish production flow and to maximize profits (RIBEIRO; ROCHA JÚNIOR, 2011). Contracts are a form of governance structure and the economic agents of agribusiness adopt them in order to achieve an appropriated coordination of production (ROCHA JÚNIOR et al., 2013). Moreover, contract farming is a possible mechanism to rule and coordinate the transactions in the agricultural production system regarding transaction costs reduction (SILVA, 2005). Unlike the mere purchase and sale operations through the open market view, when the product is delivered immediately to a price, contract farming is based on agreements settled prior to the farmer deciding about production, providing means of production coordination and safety for both farmer and agro-industry/distributor. The farmers engaged in contract farming not only have the duty to deliver the production under contract, but also the obligation to do according to the manufacturing process (BENINCASA, 1992; JANNARELLI, 2012).

Contract farming usually is a more complex long-term contract than instantaneous trade (spot market) and must in practice be incomplete (CAMPBELL; HARRIS, 2005). The emphasis of a long-term relation is put on setting methods of ruling the relationship and not variables as price and quantity at the formation stage (GOLDBERG, 1976). The problems related to the coordination of production by means of a contract farming are associated with the unpredictability of all its aspects, due to the behavioral assumption of bounded rationality. Thus, contracts are drawn on condition of incomplete information, which leads to contractual gaps.

The analysis of incomplete contracts focuses on the debate concernining the rules for fulfilling gaps, either recommended by the State or by private institutions. Third parts, as mediators, arbitrators or judges, must fulfill the gaps in the relationship between the farmer and agro-industry/distributor (ARRUÑADA, 2001). Private agents can fulfill the gaps in the relation as well. In other words, when the parts face problems created by contract farming, they have to seek solutions through legal or private resources.

The absence of a specific legal framework in Brazil, ${ }^{1}$ and the lack of autonomy of this type of contract, compared to other legal models known by the executors of the law, have led to numerous misunderstandings. Specially, when the Judiciary is called upon to settle disputes on contract farming, judges conduct it to the following legal types: futures contract;

1 This study aimed to analyze the Bill 6,459/2013. A specific law for this type of contract, Law 13,288, was only promulgated on May $16^{\text {th }}, 2016$. 
labor contract; agrarian partnership. According to Posner (1999, p. 5) : "[...] courts, which are complete foreigners to the industry and to the relationship, are not likely to have, or be able to obtain, the information that is necessary for this understanding."

It might be useful to think up State intervention through specific law for the Brazilian contractual relations in agro-industry system (AGS), in order to achieve higher security to economic agents. Insofar as the Judiciary fulfills the contractual gaps correctly, the effort to draw the contract (ink costs) and to seek the ideal partner is reduced; consequently, transaction costs are lowered. Nevertheless, despite the absence of a specific law in the Brazilian AGS, the practice of contract farming is widely spread. The study of performed contracts within the Brazilian agribusiness system provides a relevant tool for public policies and companies strategies planning (ROCHA JÚNIOR et al., 2013).

The bills that have been discussed in Brazilian Congress since 1998 reflect the need for public rules to conduct contract farming in Brazilian AGS. The appliance of a specific law for contract farming determines the suitable legal regime to concrete cases, especially for countries that adopt the rule of law as the main normative source (Civil Law system). A specific law might provide a useful legal framework for the constitution and execution of contract farming and, subsequently, its interpretation by the courts, the parts and their arbitrators.

This study aims to analyze the Bill 6,459/2013, which intends to rule contract farming and takes private instituctions into account, through the agency of the Monitoring, Development and Reconciliation of Integration Committee (Cadec). This is an applied research with qualitative approach, bibliographic and documentary procedure and analytical study of Bill 6,459/2013.

Our study analyzes aspects of the institutional environment that surrounds the formal and informal rules. The theoretical framework is based on the New Institutional Economics (NIE), focusing on transaction costs, which considers the transaction as the main unit of analysis (WILLIAMSON, 1985). In terms of transaction, it represents a transfer of good or service across technologically separable interfaces, as proposed by Williamson (1985). The transactions take place in a structured institutional environment composed by both formal and informal institutions, which influence agents' decisions (RIBEIRO; ROCHA JÚNIOR, 2011).

By applying the NIE, the analysis of contracts adopted in the agricultural production chain joins both the organizational form and the institutional environment, integrating Law, Economics and Organization (WILLIAMSON, 1990; 2005). The concepts of Law and Economic analysis promote the understanding of the real effects created by legal rule, and consider the consequences of private rules. The economic analysis of law discloses a new perspective of the Agrarian Law, when applied to contractual relationships involving farmers and other sectors of the productive system (ROSSI, 1947; GALLO, 1998).

This article is structured as follow: Section 1 presents the explanation of contract farming related to institutional arrangement. Section 2 associates institutional environment to 
contract farming. Section 3 presents a perspective of economic rights and legal rights for contract farming. Section 4 analyses the Bill 6,459/2013, and is divided into 3 subsections: 4.1 discusses the institutional environment built by Bill 6,459/2013; 4 .2 describes the various bills related to contract farming; 4.3 discusses the Cadec, considered as an informal rule. The last Section draws some conclusions.

\section{INSTITUTIONAL ARRANGEMENTS AND THE HYBRID FORM IN THE AGRO-INDUSTRY SYSTEM (AGS)}

The institutional arrangement is called form of organization (NORTH, 1971), institutional structure of production (COASE, 1992) or governance mechanism (WILLIAMSON, 1996). Ménard (2004) refers to institutional arrangement as mode of governance or organizational mode that economic agents implement their production and exchange within an institutional environment. Governance structure is the different forms of governing economic transactions; i.e., market, hybrid and hierarchy (vertical integration) (WILLIAMSON, 1991). Market is the arena in which autonomous parts engage in goods or services exchanging, without previous planning. Hybrid form is a long-term contractual relation that preserves autonomy and provides added transaction specific safeguard. Vertical integration (hierarchy) is transactions placed under unified ownership.

The offer of greater guarantees with the lowest cost of organizing a transaction must be taken into account for the appraisal of the organizational processes. The choice between two or more institutional arrangements lies on transaction costs economizing, which explains the transactions through the market or the existence of a firm (COASE, 1937). The concept of transaction cost refers to a less costly process of contracting and its ex-post alignment (WILLIAMSON, 1990). The ex-ante costs are those arising from negotiating, drafting of contracts, agreements on disputes, and the ex-post costs are for aligning and adapting the contract to unexpected situations (WILLIAMSON, 1985). Institutional arrangements should be established in order to decrease transaction costs (WILLIAMSON, 1975; 1985; 1996). In other words, transaction cost economizing is the lowest cost that allows the economic system to work, that is to say the cost of planning, adapting and monitoring the organization arrangement (WILLIAMSON, 1985).

According to Williamson (1990), choosing a specific organization form means to reduce transaction costs by aligning governance structure with transaction attributes. Therefore, the model of arrangement can change, depending on attributes of transaction - asset specificity, frequency, and uncertainty (WILLIAMSON, 1985). For North (2000), transaction cost is the cost of specifying and measuring the characteristics of what is being negotiated and the cost of forcing the contract performance.

In terms of asset specificity, it is considered the most important dimension of the transaction, which is related to the specific investments involved in a transaction. A specific 
investment cannot be replaced by other transaction without value loss (WILLIAMSON, 1985). This transaction characteristic results in a bilateral tied transaction, which conduct the transaction towards vertical integration. The reason for transaction being bilateral depended is the fact that specific investment in a transaction creates a dependency relationship. Asset specificity measure is directly proportional to the extent of specific investment and irreversibility (RIBEIRO; ROCHA JÚNIOR, 2011). The second transaction attribute is frequency, which is the number of times an economic agent performs transactions. Because of transaction frequency in a long-term contract, agents build a reputation that might constrain opportunist behavior, such as contract breach. Therefore, insofar as the transaction is more frequent, reputation will increase among the participants of transaction. In terms of uncertainty, since the assumption is that individuals have bounded rationality, the contracts are incomplete. The uncertainty is related to asymmetric information that compels the agents to make more efforts to transact. Indeed, uncertainty is the unpredictability of the attitudes of economic agents that does not allow to measure of the ex-post transaction. On the other hand, risk can be measured and safeguarded in the provision of contracts (RIBEIRO; ROCHA JÚNIOR, 2011). These transaction attributes impact the institutional arrangement choice.

Different institutional arrangements are different contracts designs performed by economic agents involved in the production system (ZYLBERSZTAJN, 2005). Coordination in the agri-food sector is represented in different ways, depending on the institutional environment of the countries. According to Ménard and Klein (2004), in England, Germany, and the Scandinavian countries there is a trend for vertical integration. Instead, in France, Italy, the Netherlands, and Spain, there is a complex institutional arrangement due to the certificate of origin of agricultural products. The arrangements in the AGS under the perspective of transaction cost economics (TCE) can be summarized into three models:

a) Spot market - The agro-industry/distributor demands for supplier/farmers at the time he needs to purchase agricultural products. The transaction is held in the spot market. In this case the transaction is governed by supply and demand.

b) Hybrid - The agro-industry/distributor performs prior agreements (written or oral contracts) with farmers to purchase the entire output at a predetermined price, for example, establishing agreement on various obligations, such as the anticipation of inputs, provision of technical assistance, rigorous monitoring for producing mode. Farmers and agro-industry/distributor are autonomous companies, but interdependent along the AGS for better control of the entire agri-food chain to match consumer demand for products with quality - this phenomenon is called quasi-integration or partial integration or integration contract. 
c) Vertical integration (Hierarchy) - The agro-industry/distributor acquires rural property and wholly develops the production life cycle of the raw material which will be used in industrialization process or trade conducted by himself - this phenomenon is called full vertical integration.

Contracts are a typical hybrid governance structure to coordinate the production (MÉNARD, 1996; WILLIAMSON; MASTEN, 1999). The main aspect of this mode of governance lies on the fact that even though the agents involved in the production system are legally independent, there is a relation of interdependence between them (TRAISCI, 1992; PRÉVAULT, 1996). Contract farming is the relation between farmers and buyers. Farmers usually provide land and human resources, grow and supply the raw agricultural commodity to the buyer who monitors the farmer production (PULTRONE, 2012). Under contract farming arrangement, the farmer is autonomous and the downstream agro-industry/distributor does not appropriate farm assets, but they specify the use of these assets (JIA; BIJMAN, 2013).

Within contract farming, different types of arrangements, contract provisions, and different services that may or may not be included in the arrangement are observed. Ménard (1996) analyzed hybrid form in the poultry sector and concluded that there are different levels of dependence among the parts engaged in the contract. He observed that coordination is stronger in long-term contracts than in short-term contracts; the contracts are incomplete and price is mostly established through negotiation. Martinez (1999) studied the hog and poultry sector and named the contract as contractual agriculture. He observed the use of interprofessional agreement to reach better equilibrium among the participants. Worley and MaCluskey (2000) researched wheat industry and they observed three types of contracts with different levels of control by the contractor: market contract; production management contract; and production contract. Jannarelli (2012, p. 250-251) presented three different contracts related to contract farming: market specification contract; resource providing contracts; management and income guaranteeing contract.

From an economic standpoint, the activity regulated by contract farming generates technological and organizational changes, and characterizes the integrated farmers as a differentiated set of farmers. In fact, integrator companies expect the integrated farmers to act as entrepreneurs and have willingness to invest, thereby seeking to ensure the steady supply of raw material and its regularity. Considering contract farming as an hybrid form, it can be observed that firms are moving away from discrete transactions and focusing more on relational exchanges (ZUURBIER; TRIENEKENS, 2000). Relational exchanges are based on longer-term interactions that involve repeated transactions. Although contracts can be short-term, related to specific projects, the contractual relationships are durable, with general contractors doing business with essentially the same partners (MÉNARD, 2004).

The long-term contract is incomplete due to the behavioral assumption of bounded rationality. Wiliamson (1990, p. 111) has written: "Transaction cost economics maintains 
that all complex contracts are unavoidably incomplete (by reason of boundary rationality)." The reason for the incompleteness of complex contract is the fact that it is impossible to address and resolve all of the relevant contracting issues in advance -ex-ante. Thus, contracting execution must be resolved ex-post by whatever governance apparatus has been provided (WILLIAMSON, 1990).

Contract farming, as well as other hybrid forms, is an institutional arrangement that economic agents implement their production and exchange within an institutional environment. The institutional arrangements are given in the institutional environment that is composed by formal and informal institutions. Therefore, the adoption of an organizational model by economic agents has an important significance for both economists and lawyers (SANTINI, 1979).

\section{INSTITUTIONAL ENVIRONMENT FOR CONTRACT FARMING}

The agro-industry system (AGS) can be analyzed with the approach of the New Institutional Economics (NIE), which takes the transaction as the main unit of analysis. The transactions in the AGS do not perform through the invisible hand, i.e., self-regulation by the price system. They consider the institutions instead. Therefore, institutions are needed to ensure the efficiency of the whole system in order to confirm the existence of the market and AGS running (FANFANI; MONTRESOR, 1998; JANARELLI, 2000; ALBISINI, 2003). Moreover, the factors that interfere in the efficiency of a business are related to the institutional environment (RIBEIRO; ROCHA JÚNIOR, 2011).

Mainly, the agro-industry/distributor influences the farmer production since they coordinate the whole chain in order to acquire safe agricultural products to attend the consumers (DE BENEDICTS; FILIPPIS, 1998). As societies become more complex in terms of the degree of interdependence, more complex institutions are required to coordinate production and exchange. According to Gabrielli (2003), the tendency of the legislature is not to consider of the contract itself and per se, but to assess economic operation in relation to its complexity. Hernández (2001) considers that the legal rules governing contracts must be able to offer a response to new demands and interests of the complexity of economic operations. Therefore, price and quantity variables at the formation stage will have less significance (GOLDBERG, 1976).

The activities in the AGS are specialized and divided into several interdependent sectors through contractual relations named contract farming. As observed by Jia and Bijman (2013), contract farming has long existed and towards the end of twentieth century it has became more important in the agricultural and food industries in both developed and developing countries. The agreements in the contract farming might be guaranteed by trusted and reputed social norms that provide self-enforcement, leading to the desired behavior (SZTAJN et al., 2005). Transactions using contract farming are interconnected 
and performed under both formal and informal institutions that are part of the institutional environment.

The institutional environment is the set of fundamental political, social and legal rules that establishes the basis for the production system (NORTH, 1990). Institutions arise, evolve, and establish the basis for production, exchange, and distribution (NORTH, 1986). However, institutions have multiple definitions; for instance, Ostrom (2008) considers institutions as rules, norms, and strategies; Dorward (2011) understands institution as culture and trust, security situation, and political system; North $(1990 ; 1991 ; 2005)$ considers institutions as rules of game composed by formal and informal rules. The rules of game define the context in which economic activity takes place (WILLIAMSON, 1996).

The purpose of North's work (1990) was to explore some characteristics of institutions for a better understanding of their involvement in economic growth. Institutions are made up of formal and informal rules that encourage behavior of private agents to design, hire and safeguarding an agreement (WILLIAMSON, 1985). According to North (1991, p. 97), "institutions are the humanly devised constraints (sanctions, taboos, customs, traditions, and codes of conduct), and formal rules (constitutions, laws, property rights)". Other classification of institutions is observed in Greif's conception (2005), which considers the formal institutions as public and informal institutions as private to provide certainty and structure to human interaction.

The distinction between public and private institutions is not so clear. For Goldberg (1976, p. 53), "[...] the line between private and public rules (restrictions) is blurred, and that to achieve desirable results society will have to erect a set of barriers or restrictions (transaction costs) to channel behavior; this set of barriers will establish a complex admixture of public and private jurisdictions". According to Goldberg (1976), the difficult is not only to define the difference between public and private rules, but in what is being regulated and not in the act of regulation itself.

The role of institutions is to reduce uncertainty and to create a favorable environment for decision-making process to exchange of goods and services (NORTH, 1990; 1991; 2000). Considering transaction costs, they are economized insofar as institutions facilitate economic exchange. In terms of formal institutions, the laws aim to facilitate trade and to settle disputes ex-post. Thus, the individual efforts for conflict solution decrease since the third parts, such as arbitrators and judges, settle the disputes (ARRUÑADA, 2001). In terms of informal rules, private participants of market guarantee the adaptation required from changes (JANNARELLI, 2000; FERRARESE, 2000). Therefore, the informal institutions are more flexible, and open-ended documents might themselves be interpreted narrowly (FERRARESE, 2002; CAMPBELL; HARRIS, 2005).

The formal institutions are important for transaction, since property rights traded on the market are established by the legal system. However, besides the formal institutions, private agents can practice self-enforcement, through informal institutions. Self-enforcement 
can be observed in long-term relations due to agents' reputation. In this sense, reputation is a form of contract enforcement and it is not necessarily based on public rules. The parts of long-term contract aim at utility maximization directly through long-term cooperative behavior manifested in trust and not in reliance on obligation specified in advance, unlikely the partnership (CAMPBELL; HARRIS, 2005).

Despite the informal institutions might provide quick solutions for long-term contracts in the AGS, the State intervention with formal institutions is important to carry out goods and services exchanges more impersonally (KEEFER; SHIRLEY, 2000). When the agents have not created a reputation or trust, the private rules might not be adequate for contract enforcement and the State intervention will be necessary. As analyzed Eggertsson (1990) when dealing with long-term contracts, State intervention is an alternative to induce specific investments, encourage contracts through government guarantees and reduce transaction costs.

In terms of formal institutions, different countries have chosen to regulate contract farming in different ways (PULTRONE, 2012). In Brazil, a significant increase in the use of contract farming as tool for coordinating agricultural, industrial, and commercial activities is observed from the 1980's. Such contracts are distinct from the multiplicity of contracts typified in the Civil Code or the Land Statute, two of the most important legal sources of Brazilian law in contractual issues. In the absence of a specific law to legally protect contract farming - as in Brazil -, the parts involved in the relationship negotiate and develop private mechanisms for contract enforcement. These private arrangements include safeguards to avoid opportunistic behavior that may arise. Thus, the reputation of parts involved in the transaction is the main aspect for the AGS running.

Although there is no specific law that regulates contract farming, well-elaborated and correct contracts provide an environment for economic development and, consequently, ensure levels of freedom that are compatible with wellfare (RIBEIRO; ROCHA JR., 2011).

On the other perspective, private and public institutions can coexist and they are complementary instruments. The complementarity view suggests that the use of both formal and informal arrangements provides more efficient outcomes than the use of either arrangement in isolation (KLEIN, 1992; LAZZARINI et al., 2004; MAZÉ, 2005; WATANABE; ZYLBERSZTAJN, 2014). The argument supporting complementarity view is the idea that incomplete formal contracts facilitate the self-enforcement of informal agreement; i.e., self-enforcement of dimensions that are non-contractible, according to Lazzarini et al. (2004).

\section{ECONOMIC RIGHTS AND LEGAL RIGHTS FOR CONTRACT FARMING}

In Brazil, contract farming is consolidated in the tobacco sector since 1918 (BONATO; ZOTTI; ANGELIS, 2010). The contract farming is widely practiced in other sectors, such as poultry, swine, dairy and flowers, as well as distributors for own-brand products. However, 
the agricultural contracts regulated in Brazil by Estatuto da Terra, Law 4,504, 30 ${ }^{\text {th }}$ November 1964, are land leasing and partnership. These contracts are related to property approach and they search for social function of property. The agricultural contracts do not need to be written due to the complexity of Brazilian reality that there are a number of illiterate in the rural environment (BORGES, 1998).

Although there is no specific law for Brazilian contract farming, these contracts are socially typical contracts, regulated by informal institutions (CONFORTINI; ZIMATORE, 1983). According to Zimatore (1988), contracts might not correspond to a legal scheme. However, they are social institutions for the circulation of wealth and the distribution of risks between the parts involved in the contract.

The importance of contract farming in Brazil arouses the interest of legislators, engendering the political discussion of bills related to contract farming since 1988. The State intervention in the contract farming would mark the transition of economic rights to legal rights, terms classified by Barzel (2002).

In terms of economic rights, each individual is able to consume and exchange goods and services without State intervention. In this sense, the owners can benefit from the rights to properties or assets without State recognition. Transactions guaranteed by economic rights would be those typically performed in a given community. The agreements are performed according to the norms of conduct stated by the community. Moreover, the parts involved in the transactions take into account the reputation for the agreements enforcement. Thus, the rights may exist even in the absence of legal rights. In terms of legal rights, the rights are those outlined by the State. The agreements guaranteed by the State are the transactions performed in the market in a more impersonal mode since the State has the power of coercion (KEEFER; SHIRLEY, 2000; GRAU, 2005).

Based on economic and legal rights, Barzel (2002) distinguishes agreements from contracts. The term agreement is widely used, while contract is strictly the agreement guaranteed by the State; therefore, contract would be part of the legal rights. Any other arrangements are related to economic rights determined by private rules, which may be self-enforced.

By treating all transactions as agreements, they must somehow be fulfilled. Each economic agent will use the method of coercion that is more advantageous, and may be through self-enforcement or seek a third party that may be an arbitrator or judge (BARZEL, 2002). Self-enforcement is determined by the reputational capital of the economic agents involved in the contractual relationship of the AGS, but does not always work well for all types of agreement, and in these cases a third party is required. In this sense, Barzel (2002, p. 34) posits as following: "Third-party enforcement often works better, because third parts are able to provide the principles to an agreement an altered set of incentives such that their net gains from interacting will exceed those they could attain under self-enforcement. Thirdparty enforcement, however, is costly and will not be used in all cases." 
According to Klein (2002), considering that self-enforcement mechanisms are limited, the parts of a contract would benefit from contractual terms. In this sense, one might consider that the traditional mechanisms of legal norms would complement the mechanisms of self-enforcement, instead of thinking that they can substitute each other. It is assumed that many relationships are informal agreements and there is a greater possibility of selfenforcement, for instance, when agreements are set in small communities. However, in many cases the agreements are given in a more impersonal way, so the reputation of the parts and the State intervention turn out to be insufficient to achieve the required assurance of due performance of the agreement.

The legal definition of the contract, according to Roppo (2001), contains three components, which are: (a) the parts involved in the agreement, so the contract is a consensual act; (b) the object of the agreement: a patrimonial legal relationship; therefore, the agreement is a patrimonial legal act; (c) the act of will to constitute, regulate or terminate the contract.

On the one hand, the contract should be subject to economic operations. On the other hand, economic operations might act as non-legal contractual form, although they may legally constitute matters of contract. This means that these economic operations tend not to adhere to the legal contractual form and follow the rules determined by private economic agents. These economic agents are performing a transfer of wealth without a formal contract, but with just a handshake. The agents involved in the transaction apply their own rules and reject the idea of formalizing the agreement on legal contractual basis because they avoid using the complex mechanism of sanction constituted by the legal rules. In this sense, the economic agents exert their economic rights.

As analyzed Roppo (2001), the question that arises is whether the agreement can create any legally meaningful relationship, since it is not a contract. Agreements can be socially valid, but they are neither part of the contractual sphere nor guaranteed by the State. The economic agents themselves determine the rules of the game that will be appreciated internally and used for dispute solution. In this sense, the economic rights act in the agreements, even if they have the patrimonial component. So the contract would be socially typical contracts where legal rights would not be applied.

The intervention of State for contract farming in the Brazilian AGS through a specific law would overcome the private sphere and reach the relations in a more impersonal mode. However, the State does not have a complete power, and private rules can coexist due to the complexity of the AGS. Thus Barzel (2002, p. 20) posits: "As the state is conventionally perceived, its actual control over power is never complete. Numerous individuals and organizations not viewed as states have power too".

In terms of contract farming, economic agents might establish agreements through economic rights. These rights may be part of the contracts that are recognized by the state; i.e., contracts are part of legal rights. In Brazil, although contract farming is widely practiced, there is no specific law and the economic agents design the contract farming with economic 
rights. However, the private institutions that are part of economic rights should operate under the shadow of law, as observed Williamson (1985). Indeed, the contract farming has the main elements for its validity provided by legal rights: I - legal capacity; II - lawful object; III - legal formalities.

Summarizing, in spite of being the structural element of the contract the agreement cannot always be regarded as contract, according to the classification of Barzel (2002). The contract should refer to patrimonial relations, while the agreement has broader application, such purely social relationship (marriage, for example). Thus, the economic rights would guarantee the agreement, while legal rights would guarantee the contract. In this nebulous mass to determine if the relation is contract or agreement, there is the assumption that contract refers to a legal relationship. The legal discipline of contracts is a positive action by the legislature that meets certain requirements and neglects others, seeking cover in economic operations as political interests.

\section{Analysis}

Contract farming has become more important in agricultural and agro-industries in both developed and developing countries (JIA; BIJMAN, 2013). In Brazil, significant part of the production of vegetables, fruit, and livestock for industrial processing is produced through contract farming. Indeed, the significant growth and importance of poultry and swine supply chain is due to the adoption of innovative productive system through contract farming (RIBEIRO; ROCHA JR., 2011; SOUZA; ZYLBERSZTAJN, 2011; SOUZA; BÁNKUTI, 2012; BÁNKUTI; SOUZA, 2014). Besides food sector, contract farming is used in the biodiesel production system with the intervention of State that requires the purchase of feedstock produced by family farmers (PAIVA, 2009; SILVA JÚNIOR et al., 2013). However, as many countries, Brazil has no specific law for contract farming.

In terms of informal institutions, agreements with elements of transparency and mutual gains are required. In this context, it is observed that many internal disputes occur within the organization, because numerous rules are internal and the agents involved in the relationship themselves are in charge of the knowledge and functioning of the organization. The State intervenes to issues, such as disputes between firms regarding prices, damage caused by delays, amongst others (WILLIAMSON, 2005). Disputes that could be brought to the Court are resolved internally, and the organization acts as a Court of Justice of first instance (ARRUÑADA, 2000; MÉNARD, 2004; WILLIAMSON, 2005).

According to Paiva (2005), there are few demonstrations of conflict solutions on those contracts in Judiciary field. It is assumed that the cause of low judicial demand could be the adoption of mediation to resolve disputes between parts. Moreover, the organization where the transactions occur would represent the Court of the First Instance because the conflict solution would be internally held. Another aspect to be considered is the economic imbalance 
of the parts, being agroindustry economically superior to farmers. This would inhibit farmers from making any complaint through traditional mechanisms of justice, because this posture could exclude them from future negotiations.

The lack of a specific legal framework for contract farming in Brazil leads to misjudged legal decisions. Labor issue is observed in sentences of the Brazilian Labor Justice. The trend observed is that judges consider an indirect employment relationship between the integrated producer and integrator agro-industry/distributor, and in some cases, they even consider the employment relationship between employees of integrated producer and integrator agro-industry. It was observed that a sentence rendered by the Labour Court in Matão, $15^{\text {th }}$ Region, State of São Paulo, in a lawsuit filed by the Labour Public Prosecutor against Sucocítrico Cutrale Ltd., Louis Dreyfus Commodities Agroindustrial S/A, Citrovita Agro Industrial Ltd, and Fischer S/ A condemning them to abstain hiring farmers to perform activities, such as production and harvesting citrus fruits that are used in the industry activity (juice production) (BRASIL, 2013). These misjudgements happen because judges can't gather all information they need. Indeed, Posner (1999, p. 14) posits the following: "It is assumed that courts are not able to acquire the information that they would need in order to determine liability and harm."

As stated by Ribeiro and Rocha Júnior (2011), broiler farmers in Paraná State (South of Brazil) and agroindustry performed the contract in order to avoid possible labor claims. Therefore, the contracts signed are more a tool to safeguard the interests of agro-industries than to regulate the negotiation, since there is no great risk of contract breach. However, when the conflicts reach the court, according to the economic analysis of law, the judge should simulate a hypothetical negotiation of how the parts should make the contract to find the most efficient solution.

Brebbia and Malanos (1997) argued that the complexity of contract farming and the difficult to adapt it to typified contracts in the legal framework led some Europeans legislators, such as in France and Italy, regulate it (JANNARELLI, 1981; PAVONE LA ROSA, 1990). However, when dealing with legal rules, gaps and failures might happen due to the impossibility of following the transformation of the society. In other words, legislators are unable to predict all needs of the society. Thus, Cavalcanti (1964, p. 100) stated that:

Such failures were revealing, on one hand, that the state law was not sufficient to meet social needs and, on the other hand, that outside the legislated right, there were other data and elements that the judge could and should rely, whenever the right emanating from official agencies be insufficient.

Even though it is not possible for legislators predict a complete law, it is expected that typification of contract farming in Brazilian legal framework would enables higher incentives for achieving more impersonal contracts. In this sense, a specific law for contract farming in 
Brazil would assure higher legal certainty for economic agents, which allows smaller efforts in writing contracts and, consequently, lower transaction costs.

The economic sectors (associations of producers and agro-industries) involved in contract farming focused on discussion of the content of legislative proposals for a consensus on a future law. As result, two bills are pending in Congress: the Bill 330 originated in the Senate and the Bill 8,023/2010 originated in the House of Representatives. Both bills were gathered into Bill 6,459/2013, which intends to rule contract farming.

The Bill 6,459/2013 establishes the main requirements for integrated producers and integrator, mechanisms of contractual transparency, and the creation of informal institutions as the Monitoring, Development and Reconciliation of Integration Committee (Cadec). The analysis of Bill 6,459/2013 is divided into three subsections: 4.1 presents the Bill 6,459/2013 that would compose the institutional environment; 4.2 focuses on the formal rules for contract farming; and 4.3 analysis the Cadec as informal rule.

\section{I INSTITUTIONAL ENVIRONMENT: FORMAL AND INFORMAL INSTITUTION OF THE BILL} $6,459 / 2013$

Formal and informal institutions compose the institutional environment that provides a set of incentives and deterrents for agents. In other words, institutional environment is: "The rules of the game that define the context in which economic activity takes place. The political, social, and legal ground rules establish the basis for production, exchange and distribution." (WILLIAMSON, 1996, p. 378).

In terms of formal institutions, the Bill 6,459/2013 might be a formal rule when it is approved and become an applicable law. Only for analysis perspective, we'll consider the Bill 6,459/2013 an applicable law. The complementarity between informal and formal institutions is observed in the Bill 6,459/2013 (Figure 1). The complementarity view suggests the use of public and private institutions provide more efficient outcomes than the use of each institution individually (KLEIN, 1992; MAZÉ, 2005). Formal institutions are the rules determined by the State, such as the Bill 6,459/2013. Informal institutions are economic and social sanctions defined and applied by private agents, such as the rules established in Cadec. 
FIGURE 1 - FORMAL INSTITUTIONS AND ITS COMPLEMENTARITY WITH INFORMAL INSTITUTIONS

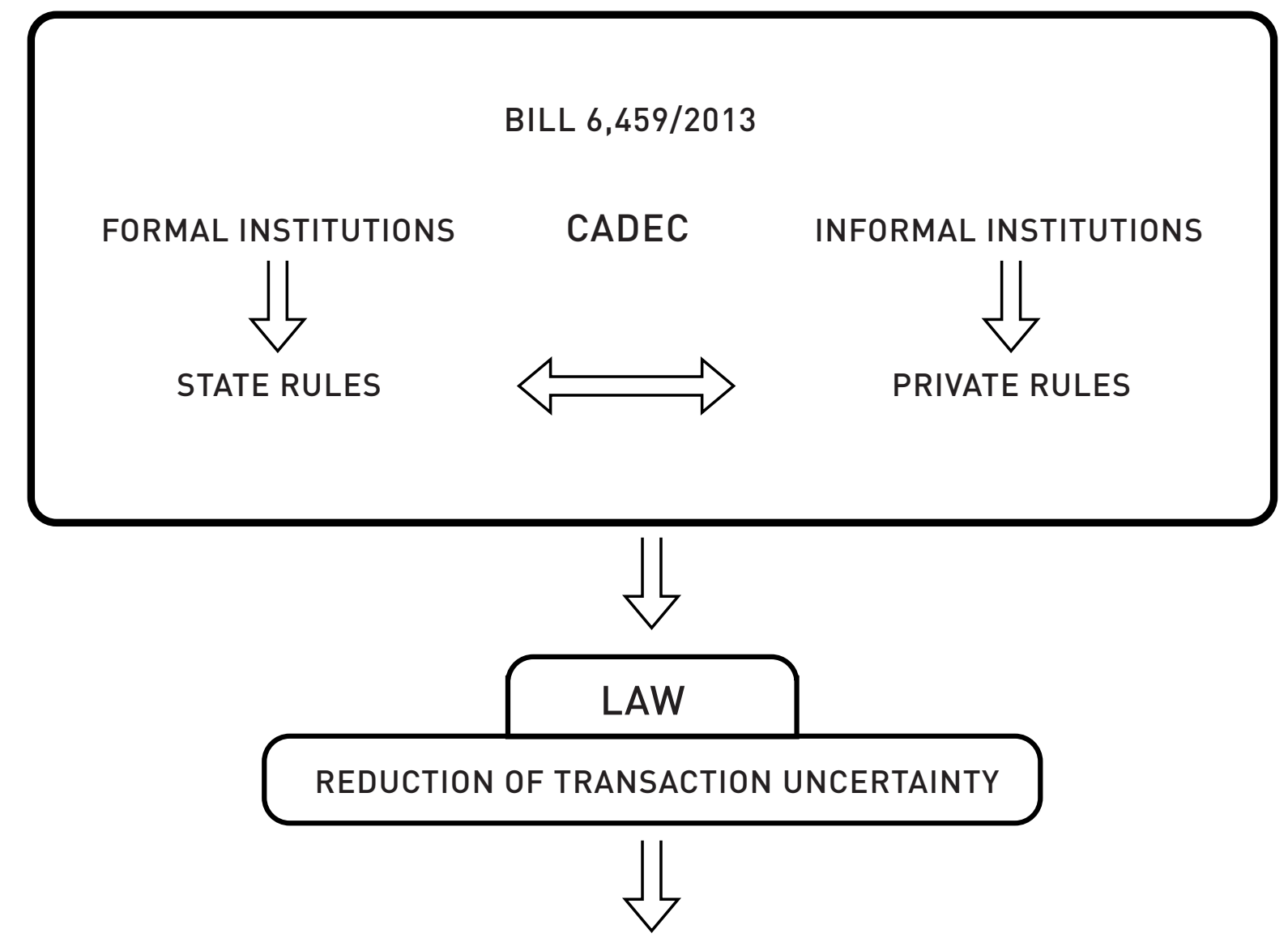

\subsection{FORMAL RULES FOR CONTRACT FARMING}

In terms of formal rules, the State intervenes and establishes them. Considering the importance of legal regulation of contract farming, the economic sectors (association of producers and agroindustry) focused on the discussion of the content of legislative proposals for a consensus of future law. The first attempt to develop a specific law for contract farming in Brazil took place on April 7, 1998, with the Bill 4,378/98. On September 12, 2001, amendments to the Bill 4,378/98 were raised in relation to the rights and obligations of each part, disregarding what was presented on April 7, 1998. The objection to the original text was due to the impossibility of industries bear the costs.

The Bill 6,459/2013 uses the nomenclature 'vertical integration contracts' in agroforestry activities, showing from the start economical operation performed in contractual type. The Bill 6,459/2013 defines the following parts on the agroforestry integration contracts:

Integrated Producer: agroforestry and animal farmer, agrarian company, individually or in association with others, that is linked to the integrator through the integration contract, 
receiving goods or services for production and providing raw materials for integrator, goods intermediate or final consumption goods.

Integrator: individual or company that is linked to integrated through integration contract that furnishes goods, supplies and services and receiving raw materials, intermediate goods and final consumer goods used in industrial or commercial process.

In terms of definitions of the parts, the bill makes it clear that may farmers and agroindustry in the form of physical or legal person, including the figure of the cooperative, be parts of the contract farming. The bill specifically excludes the vertical integration relationship established between cooperative members and the cooperative, or cooperatives among themselves, because it represents horizontal modalities and not vertical integration, governed by a specific law of cooperative activity. However, relations between cooperatives members and cooperatives can be characterized as a contract farming when the members are encouraged to purchase the input of the cooperative and surrender all production to it.

The concept of integrated producer elected by the Brazilian legislature has focused on the nature of the goods produced, which are related to the exploitation of natural resources, primary (agriculture, livestock, forestry and aquaculture). The bill does not specify the intermediate goods, such as honey, processed coffee, silk etc., which are produced by the integrated producer and supplied by the integrator.

Brazilian legislators also chose to embrace the relationship between the farmer and the merchant (retailer, wholesaler or exporter) in the concept of contract farming, since it is not simple transaction of buying and selling. To characterize contract farming, mutual supply of goods and services, or the presence of interdependence of parts is necessary.

In order to make clear that the figure of contract farming cannot be confused with employment relationship, the Brazilian bill provides, precisely in art. 2, paragraph 3, that civil relationship defined under this Act, does not constitute the provision of services or employment relationship between integrator and integrated, his agents or his employees. The inclusion of this paragraph in the body of the bill stems from numerous decisions of the Labour Court considering the existence of labor ties between producer and industry, or the subsidiary responsibility of the industry in the face of employees or service providers linked to the integrated producer. Thus, they do not recognize the economic and legal autonomy of integrated producers.

The term 'control' does not appear in the text of the Brazilian bill. Such feature is replaced by the idea of cooperation between integrated producer and integrator. Under the bill, the guidance of all law enforcement and interpretation principle is that the relationship of contract farming is a pooling of resources, efforts and the fair distribution of income.

The main obligations of the parts are: 
a) Integrated producer: performs activities of growing, breeding or extracting plant or animal feedstock, with respect to the agreed technical specifications; delivers the entire production agreed that corresponds to pre-set criteria of quantity and quality.

b) Integrator: receives all production contracted; pays the pre-set price and exercises control and inspection of the production phase performed by the integrated producer.

However, the agreements between the parts have a number of other ancillary obligations such as providing packaging, transport, advanced credit, input supply and technical assistance.

The Bill 6,459/2013 stipulates in its article 4 the minimum content that must be observed by parts to contracts under penalty of nullity. It is observed that the sections I through IX refer to mandatory clauses, which are intended to make contractual relationship more transparent, thus helping to reduce opportunities for contract breach. Note that the integrator usually drafts the contract farming for integrated producer adhesion of preset clauses.

The sections of the X until XIII provide the rules of tax liability, environmental and health, as well as allowing parts to establish accessory contract of insurance as mandatory.

The item XIV expresses important rule about minimum contract duration, as well as the prior notice period for termination of the productive cycle of activity and investments made by the parts. The goal is to protect the entrepreneur (integrated producer or integrator), especially the integrated producer who is the possible weak part in the chain of unilateral contract termination, which may cause damage since much of the investment employed only produce financial returns in the medium to long term.

Finally, item XV provides for the creation of Cadec (Monitoring, Development and Integration of Reconciliation Committee). Each unit of the integrator agroindustry and integrated producers must constitute Cadec unless the structure of the supply chain already exists a similar institution.

The Bill 6,459/2013 determines the development of the Information Report of Integrated Production (RIPI) and the Information Document Pre-Contract (DIPC) to reduce the information asymmetry. In spite of the determination of the formal rule, these documents consist on private agents' control.

In terms of RIPI, integrator agroindustry should organize the report for each production cycle of integrated producer. This report contains information on the inputs provided by the integrator, the phytotechnical and zootechnical indicators of integrated production, the quantities produced, productivity rates and prices used in the reckoning of financial results, and other information specified by the Monitoring, Development and Reconciliation of Integration Committee (Cadec).

In terms of DIPC, integrator agroindustry provides information for those interested in joining the production system. This document will be updated quarterly and will contain 
information with data from the integrator agroindustry, the description of the integrated production system, health and environmental requirements and economic risks of the activity, the estimated investment in facilities or growing areas, the estimated share of the integrated by livestock or harvest cycle, the alternatives of agricultural finance institution or integrated agroindustry, technical and economic parameters set by the integrator for the study of economic, and financial feasibility of the project financing of the project.

The Bill 6,459/2013 asserts in its Article 6 that each unit of integrator agro-industry and integrated should be integrated to Cadec, unless already exists commission or similar entity.

\subsection{INFORMAL RULES IN CONTRACT FARMING - CADEC}

The Bill 6,459/2013 is a mean to grant a theoretical framework for the State intervention, so it can be fairly interpretated by the judiciary system. However, it establishes rules that would be conducted by private agents. The Bill 6,459/2013 introduces institutions that will be able to operate in a social context made up of complex rules, public and private rules, legal and economic rights, developed from authority and through negotiation. Informal institutions have a more flexible method of action that allows the agents to make renegotiation and obtain a better adaptation in a dynamic environment.

According to Bobbio (2007), the theory of the institution expands the horizons of legal experience beyond the limits of the State. Thus, the theory of the institution broke the closed circle of statist theory of law, which considers only the State law. Institutions arise from the process by which the principles of coordination are accepted locally and are adopted by a growing number of agents until they become a generic and unique basis for coordination. Agreements between integrated farmers and integrator agro-industries arise through negotiations and are willingly accepted as rules.

According to the Bill 6,459/2013, agents that form the Cadec would agree on the adoption of common rules for coordination and decision-making mechanisms, creating, adapting or adding them to the current rules. Therefore, organizations undertake negotiations that are accepted as rules, creating institutions that may become generic and mandatory for agents that are part of contract farming.

The main objective of Cadec is to expedite transactions between the integrated agricultural producer and the integrator agro-industry, providing a forum for conciliation and settlement of disputes amid them. The normative rules of the State do not replace the specific regulations of each private agricultural sector, but can complement them.

Economic agents can employ these associations to facilitate the adoption of actions. The interest of the agent for collective action emanates from its superior efficiency at achieving coordinated solutions as compared to the agreements performed individually. Individual negotiations can be costly compared to collective agreements. These common agreements would be conducted by private norms, i.e., private rules determined by Cadec 
A producer can enroll at an association of agricultural producers as a discrectional act, based both on individual and collective interest. The rules are supposed to satisfy the interests of association members by offering better terms of coordination and negotiation compared to individual acts. The same principle is applicable to Cadec; however, the participation of the integrated producers and the integrator agro-industry in Cadec's formation is mandatory since it is stated in the Bill 6,459/2013.

The Cadec would be similar to the interprofessional agreement that develops tools for mediation whereby farmers can negotiate more balanced conditions with agro-industry or distributor, which, usually, have greater bargaining power. Interprofessional agreement minimizes disputes between the parts and avoids the solution of conflicts by traditional mechanism of legal Courts, which saves transaction costs (SIRSI, 1990; MAZÉ, 2005).

Institutional arrangements are structured based on relational contracts, for example, when the informal institutional norms prevail; the parts make agreements internally through Cadec. The parts involved in Cadec may hold informational advantages over the bodies of the Judiciary. Therefore, according to Ulen (1984), the parts already have all the knowledge of trading, while the judge would have to take knowledge of the contractual terms, the object traded, the market, and a lot of information that can be quite complex to no anyone not involved in the relationship. Therefore, it is expected that the transaction costs of settlement of disputes are resolved internally when smaller, because of informational advantages of contractors in relation to the Courts. According to the analogy of Williamson $(1996 ; 2005)$, Cadec could be the Court of first instance, where different types of disputes are resolved.

Another aspect to be taken into account when it comes to the reduction of transaction costs is the increased level of confidence that the contractual relationship inspire to the parts, which integrates the reputation for the contract performance. The relational development has long-term implications, since the parts, even with latent conflict, develop informal negotiation mechanisms of great complexity.

If the informal norms prevail, rather than explain all contractual terms ex-ante, parts may rely on private mechanisms to enforce the contract. The reputation of the agents is an important private mechanism and represents the previous actions of quasi-rents appropriation arising from specific investment. Klein (1992) notes two aspects regarding the appropriation of quasi-rents: (1) the risk of termination of the relationship; (2) the loss of reputation of the agent before the market it serves. On the other hand, the explicit contractual terms, even though the State has no major role at the fulfillment of the contract, can complement the institutions of private ordering, suggesting potential sanctions that affect the cost of the contract breaching. The two classes of institution for contract farming - public and private institutions - interact according to the Bill 6,459/2013.

If the Bill 6,459/2013 passes, it would be the legal rights for contractual relations in the AGS. However, because of the complexity of the AGS, the agents involved in the transaction 
determine a great number of norms, which would not necessarily be brought to the attention of the State. The Cadec provides private rules for the achievement of agreements between integrated producer and integrator agroindustry. Therefore, these private rules would be economic rights. These rules may be part of the contract recognized by the State. In this sense, we would consider that the legal rights would be complementary to economic rights concerning the operation of the AGS, since both legal and economic rights can coexist.

\section{CONCLUSION}

In the Brazilian AGS, because of the lack of a specific Law for contract farming, economic agents create their own rules (economic rights). The lack of a positive norm leads the agents to create institutions for guaranteeing agreements (or the courts will base their decisions on rules of commercial law or similar for conflicts solutions in contract farming). On the other hand, private institutions may not be sufficient, and it highlights the importance of public institutions, since they assure greater legal certainty, and reduce the ex-ante efforts for contractual relations in the AGS, leading to transaction costs reduction. In this sense, we would consider that the legal rights would be the complement of economic rights to operate the AGS, because both rights can coexist.

The legal regulation of contractual relations in the AGS is an extension from rules stipulated by private economic agents. The relevance of private rules for contractual relations in the AGS is such a complex issue that we can't state if it is better or worse than the public rules. Our assertment is that the adoption of mixed regimes contributes to the improvement of the coordination of AGSs.

According to the Bill 6,459/2013, informal norms presented in contract farming are guaranteed by the State through Cadec. Informal rules cover social norms to explain the operation of the production system. The Bill 6,459/2013 does not regulate all aspects of trading, leaving the regulation of particulars to the autonomy of Cadec. This suggests the hybrid characteristic of the agreements, situated between the State dirigisme and private autonomy. Private rules of coordination, that is, organizations of the transactions between farmers and agro-industry/distributor by means of CADEC might be an effective way of economic and technical coordination.

Thus, if the Bill 6,459/2013 passes, it might encourage the development of normative agreements signed by the entities representing farmers and industries involved in the integration system - Cadec, which form a more equitable basis, better coordination of production and ease of transaction, leading to transaction costs reduction. The proposed formation of Cadec is interesting since it increases the transparency of information and the contractual balance; therefore, allowing the transaction costs reduction. However, the effectiveness of Cadec is uncertain because there is no specific incentive for this to occur. Future research should be addressed to this issue. 


\section{ACKNOWLEDGEMENTS}

This article is a new version of previously presented in the IX RWIO. We thank Rubens Nunes for discussing the earlier version in the IX RWIO. We also thank Wagner Luiz Lourenzani for his comments on early versions of this paper. The financial support of Capes for pos-doc program is acknowledged.

\section{REFERENCES}

ALBISINNI, Ferdinando. Sistema agroalimentare. Digesto delle Discipline Privatistiche. Sezione Civile. Tomo II. Torino: UTET, p. 1244-1261, 2003.

ARRUÑADA, Benito. The quasi-judicial role of large retailers: an efficiency hypothesis of their relation with suppliers. Revue d'Economie Industrielle, n. 92, p. 277-296, $2^{\text {nd }}$ and $3^{\text {rd }}$ trimester, 2000.

ARRUÑADA, Benito. The role of institution in the contractual process. In: DEFFAINS, Bruno; KIRAT, T. Law and economics in civil law countries. Amsterdam: Elsevier Science, 2001. p. 149-167. (The Economics of Legal Relationships Series).

BANKUTI, S. M. S.; SOUZA, J. P. Arranjos contratuais e assimetria de poder no SAG suinícola no Oeste Paranaense. Organizações Rurais e Agroindustriais (UFLA), v. 16, p. 92-107, 2014.

BARZEL, Yoram. A Theory of the State. Economic rights, legal rights and the scope of the state. Cambridge: Cambridge University Press, 2002.

BENINCASA, Maurizio. Il problema della tipicità dei contratti agro-industriali. Il diritto dell'agricoltura. Napoli: Edizione Scientifiche Italiane, 1992. v. 1.

BOBBIO, Norberto. Teoria geral do direito. Tradução: AGOSTINETTI, Denise. São Paulo: Martins Fontes, 2007.

BONATO, Amadeu; ZOTTI, Cleimary Fatima; ANGELIS, Thiago de. Tabaco da produção ao consumo. Uma cadeia de dependência. Curitiba: DESER, 2010. Available at: <http://www.deser.org.br/ publicacoes/revistaTabaco-ElaboraçãoDeser-ACT.pdf> . Accessed: Mar. 30, 2017. 
BORGES, Paulo Torminn. Institutos básicos do direito agrário. São Paulo: Saraiva, 1998.

BRASIL. Projeto-lei $\mathrm{n}^{\circ}$ 4.378, de 7 de abril de 1998. Regula as relações jurídicas entre a agroindústria e o produtor rural integrado e dá outras providências. Available at: <http: / /www.camara. gov.br/internet/sileg/Prop_Detalhe.asp?id=20847 > . Accessed: Mar. 30, 2017.

Projeto-lei n 8.023, de 15 de dezembro de 2010. Dispõe sobre a integração vertical na agropecuária, estabelece condições e responsabilidades nas relações jurídicas entre a agroindústria e o produtor rural integrado e dá outras providências. Available at: <http: / /www.camara.gov.br/ proposicoesWeb/fichadetramitacao?idProposicao=489913>. Accessed: Mar. 30, 2017.

Projeto-lei no 330/2011, de 15 de junho de 2011. Dispõe sobre a parceria de produção integrada agropecuária, estabelece condições, obrigações e responsabilidades nas relações contratuais entre produtores integrados e agroindústrias integradoras e dá outras providências. Available at: $<$ http: / / www.senado.gov.br/atividade/materia/detalhes.asp?p_cod_mate=100728>. Accessed: Mar. 30, 2017.

. Projeto-lei $n^{\circ} 6.459$, de $1^{\circ}$ de outubro de 2013. Dispõe sobre a integração vertical na agropecuária, estabelece condições e responsabilidades nas relações jurídicas entre a agroindústria e o produtor rural integrado e dá outras providências. Available at: <http: / /www.camara.gov.br/ proposicoesWeb/fichadetramitacao?idProposicao=594069>. Accessed: Mar. 30, 2017.

Justiça do Trabalho $15^{a}$ Região - Vara do Trabalho de Matão. Ação Civil Pública. Proc. 88.2010.5.15.0081. Ministério Público do Trabalho e Sucocítrico Cutrale Ltda; Louis Dreyfus Commodities Agroindustrial S/A; Citrovita Agro Industrial LTDA; Fischer S/A - Comércio, Indústria e Agricultura. Relator: Flavio Allegretti de Campos Cooper. Sentença 13 mar. 2013. Available at: <http: / / s.conjur.com.br/dl/sentenca-atividade-fim-producao-suco.pdf>. Accessed: Mar. 30, 2017.

BREBBIA, Fernando P.; MALANOS, Nancy. Derecho agrario. Buenos Aires: Astrea, 1997.

CAMPBELL, David; HARRIS, Donald. Flexibility in long-term contractul relationships: the role of co-operation. Lean Construction Journal, v. 2, n. 1, April 2005.

CAVALCANTI FILHO, Teophilo. O problema da segurança no direito. São Paulo: Revista dos Tribunais, 1964.

COASE, Ronald. The nature of the firm. Economica, v. 4, p. 386-405, 1937.

The institutional structure of production. American Economic Review, v. 82, n. 4, p. 713719, Sept. 1992. 
CONFORTINI, Massimo; ZIMATORE, Attilio. Contratti agro-industriali. In: IRTI, Natalino (a cura di). Dizionari del diritto privato. Diritto Agrario. Milano: Giuffrè, 1983. v. 4.

DE BENEDICTIS, Michele; DE FILIPPIS, Fabrizio. L'intervento pubblico in agricoltura tra vecchio e nuovo paradigma: il caso dell’ Unione Europea. La Questione Agraria, n. 71, p. 7-65, 1998.

DOWARD, Andrew. The effects of transaction costs, power and risk on contractual arrangements: a conceptual framework for quantitative analysis. Journal of Agricultural Economics, v. 52, p. 59-73, 2001.

EGGERTSSON, Thráinn. Economic behavior and institutions. Cambridge: Cambridge University Press, 1990.

FANFANI, Roberto; MONTRESOR, Elisa. Instituzioni ed imprese nel percorso di sviluppo dei sistemi locali di produzione agroalimentare.La Questione Agraria, n. 69, p. 87-108, 1998.

FERRARESE, Maria Rosaria. Le istituzioni della globalizzazione. Bologna: Il Mulino, 2000. . Il diritto al presente. Globalizzazione e tempo delle istituzioni. Bologna: Il Mulino, 2002.

GABRIELLI, Enrico. Il contratto e l'operazione economica. Rivista di Diritto Civile, Padova, CEDAM, p. 93-114, 2003.

GALLO, Paolo. Introduzione al diritto comparato. Analisi economica del diritto. Torino: G. Giappichelli, 1998. v. III.

GOLDBERG, Victor. Regulation and administered contracts. The Bell Journal of Economics, v. 7,n. 2, p. 426 448, 1976.

GRAU, Eros Roberto. O direito posto e o direito pressuposto. São Paulo: Malheiros, 2005.

GREIF, Avner. Commitment, coercion, and markets: the nature and dynamics of institutions supporting exchange. In: MÉNARD, C.; SHIRLEY, M. (Eds). Handbook of new institutional economics. Dordrecht: Springer, 2005. p. 727-786.

HADFIELD, Gillian K. The many legal institutions that support contractual commitments. In: MÉNARD, C.; SHIRLEY, M. (Eds). Handbook of new institutional economics. Dordrecht: Springer, 2005. p. 175-204.

HERNÁNDEZ, Angel Sánchez. Teoria General del contrato agrario. In: MASSART, Alfredo; HERNÁNDEZ, Angel Sánchez (Orgs.). Manual de instituciones de derecho agroambiental Euro-Latinoamericano. Pisa: Ets, 2001. 
JANNARELLI, Antonio. Disciplina legale e prassi applicativa nei contratti di integrazione verticale in agricoltura: l'esperienza francese. Rivista di diritto agrario, Milano, Giuffrè, anno 60, p. 327-393, 1981.

. Istituzioni e mercato, nel governo del "sistema agricoltura”. Rivista di Diritto Agrario, Milano, Giuffrè, anno 79, p. 523-557, 2000.

Contractual frameworks and inter-firm co-operation in the agricultural sector. Uniform Law Review, v. 1-2, p. 247-262, 2012.

JIA, Xiangping; BIJMAN, Jos. Contract farming: synthetic themes for linking farmers to demanding markets. In: SILVA, Carlos A. da; RANKIN, Marlo (Edited). Contract farming for inclusive market access. Rome: FAO, 2013. p.21-38.

KEEFER, Philip; SHIRLEY, Mary M. Formal versus informal institutions in economic development. In: MÉNARD, Claude. Institutions, contracts and organizations. Cheltenham; Massachusetts: Edward Elgar, 2000. p. 88-107.

KLEIN, Benjamin. Contracts and incentives: the role of contract terms in assuring performance. In: WERIN, Lars; WIJKANDER, Hans. Contract Economics. Oxford: Blackwell Pub, 1992. p. 149-180.

The role of incomplete contracts in self-enforcing relationships. In: BROUSSEAU, Eric; GLACHANT, Jean-Michel. The economics of contracts. Cambridge: Cambridge University Press, 2002. p. 59-71.

LAZZARINI, SERGIO G.; MILLER, GARY J.; ZENGER, TODD R. Order with some law: complementarity versus substitution of formal and informal arrangement. The Journal of Law, Economics and Organization, Oxford University Press, v. 20, n. 2, 2004.

MARTINEZ, Steve W. Vertical coordination in the pork and broiler industries: implications for pork and chicken products. In: FOOD AND RURAL ECONOMICS DIVISION, ECONOMIC RESEARCH SERVICE/USDA. Report n. 777. April 1999.

MAZÉ Armelle. Contract law and the range of self-enforcing contracts in agriculture: private institutions and multilateral-reputation mechanisms. Second French and Germany Talks in Law and Economics, Sarebrucken, v. 2-3, Dec. 2005.

MÉNARD, Claude. On clusters, hybrids, and other strange forms: the case of French poultry industry. Journal of Institutional and Theoretical Economics, v. 152, p. 154-183, 1996. 
MÉNARD, Claude. L'économie des organisations. Paris: Repères, La Découverte, 2004.

MÉNARD, Claude; KLEIN, Peter G. Organizational issues in the agrifood sector: toward a comparative approach. American Journal of Agricultural Economics, v. 86, n. 3, p. 746-751, August 2004.

NORTH, Douglas C. Institutional change and economic growth. The Journal of Economic History, v. 31, n. 1, [The Task of Economic History], Mar. 1971.

The new institutional economics. Journal of Institutional and Theoretical Economics, v. 8, 1986.

Institutions, institutional change and economic performance. Cambridge: Cambridge University Press, 1990.

Institutions. Journal of Economic Perspectives. v. 5, p. 97-112, November I, 1991.

A revolution in economics. In: MÉNARD, Claude. Institutions, Contracts and Organizations. Cheltenham; Massachusetts: Edward Elgar, 2000. p. 37-41.

Institutions and the performance of economies over time. In: MÉNARD, C.; SHIRLEY, M. M. (Eds.). Handbook of new institutional economics.. The Netherlands: Springer, 2005. p. 21-30.

OSTROM, Elinor. Developing a Method for Analyzing Institutional Change. In: BATIE, Sandra; MERCURO, Nicholas (Eds.). Assessing the evolution and impact of alternative institutional structures. London: Routledge Press, 2008.

PAIVA, Nunziata Stefania Valenza. Os contratos de integração vertical agroindustrial: a viabilidade de uma disciplina legal em face da prática contratual brasileira. Dissertacão (Mestrado em Direito) - Faculdade de Direito da Universidade Federal de Minas Gerais, Belo Horizonte, 2005.

PAIVA, Nunziata Stefania Valenza. Novos modelos contratuais para uma nova matriz energética. Aspectos jurídico-econômicos para produção de biocombustíveis no Brasil. Revista de Informação Legislativa, ano 46, n. 184, out.-dez. 2009.

PAVONE LA ROSA, Antonio. Profili della nuova disciplina dei contratti agro-industriali. In: MASSART Alfredo (Org.). Accordi interprofessionali e contratti agroindustriali. Problemi di inquadramento giuridico. Pisa: ETS, 1990.

POSNER, Eric A. A theory of contract law under conditions of radical judicial error. John M. Olin Law \& Economics Working Paper, n. 80 [2D Series], 1999. 
PRÉVAULT, Jacques. Contrat d’intégration en agriculture. Encyclopédie Dalloz - Civil IV. Octobre 1996.

PULTRONE, Caterina. An overview of contract farming: legal issues and challenges. Uniform Law Review, v. 1-2, p. 263-289, 2012.

RIBEIRO, Marcia Carla Pereira; ROCHA JUNIOR, Weimar Freire. Institutional environment and contracts: a case study in the agroindustrial system of broiler factory farming in the west of the state of Paraná, Brazil. Revista Direito em (Dis)Curso, Londrina, v. 4, n. 1, p. 2-14, jan.-jul. 2011.

ROPPO, Vicenzo. Il contratto. Milano: Giuffrè, 2001.

ROSSI, Bruno. Economia e diritto come metodi diversi per lo studio dell'agricoltura. Rivista Trimestrale dell'Istituto Nazionale di Economia Agraria, Roma, v. II, n. II, p. 110-122, 1947.

SANTINI, Gerardo. Il commercio. Saggio di economia del diritto. Bologna: Il Mulino, 1979.

SILVA JÚNIOR, Aziz Galvão da; CLEMENTE, Felippe; PEREZ, Ronaldo. Inclusion of small-scale farmers in the Brazilian biodiesel production chain. In: SILVA, Carlos A. da; RANKIN, Marlo (Eds.). Contract farming for inclusive market access. Rome: FAO, 2013, p. 183-196.

SILVA, Carlos Arthur B. The growing role of contract farming in agri-food. FAO, 2005.

SIRSI, Eleonora. Profili metodologici dello studio sui contratti agro-industriali. In: MASSART, Alfredo (Org.). Accordi interprofessionali e contratti agroindustriali. Problemi di inquadramento giuridico. Pisa: ETS, 1990.

SOUZA, José Paulo; ZYLBERSZTAJN, Decio. Poder de mercado e poder de contrato envolvendo integrados cooperados e não cooperados: percepções na cadeia de frango. Informações Econômicas [internet], v. 41, p. 2-13, 2011. Available at: <http://www.iea.sp.gov.br/ftpiea/publicacoes/ IE/2011/tec3-0711.pdf>. Accessed: Apr. 12, 2017.

SOUZA, José Paulo; BANKUTI, Sandra M. S. Uma análise dos contratos no sistema agroindustrial suinícola no Oeste Paranaense pela ótica da mensuração e da transação. Informe GEPEC [internet], v. 16, p. 1-15, 2012. Available at: <http:/ / e-revista.unioeste.br/index.php/gepec/article/view/5144>. Accessed: Apr. 12, 2017.

STAJN, Rachel; ZYLBERSZTAJN, Decio; AZEVEDO, Paulo Furquim de. Economia dos contratos. In: ZYLBERSZTAJN, Decio; SZTAJN, Rachel. Direito \&economia. Rio de Janeiro: Elsevier, 2005 . p. 102-136. 
TRAISCI, Francesco Paolo. I contratti di integrazione verticale in agricoltura in Francia, Germania e Italia. Rivista di Diritto Agrario, Milano, Giuffrè, anno 71, p. 551-594, 1992.

ULEN, Thomas. The efficiency of specific performance: toward a unified theory of contract remedies. Michigan Law Review, v. 83, n. 63, 1984.

WATANABE, Kassia; ZYLBERSZTAJN, Decio. Contract farming in the Brazilian agribusiness system: private instituion and State intervetion. Uniform Law Review, August 2014.

WILLIAMSON, Oliver. Markets and hierarchies: Analysis and antitrust implications. New York: Free Press, 1975.

The economic institutions of capitalism. Firms, markets, relational contracting. New York: Macmillan, 1985.

A comparison of alternative approaches to economic organization. Journal of Institutional and Theorectial Economics, v. 146, p. 61-71, 1990.

Comparative Economic Organization: The Analysis of Discrete Structural Alternatives. Administrative Science Quarterly, v. 36, n. 28, 1991.

The mechanism of governance. New York: Free Press, 1996.

.Why law, economics and organization? Annual Review of Law and Social Science, v. 1, p. 36996, 2005.

WILLIAMSON, Oliver E.; MASTEN, Scott E. The economics of transaction costs. Series: Elgar Critical Writings readers, 1999. p. 101-128.

WORLEY, Thomas; MCCLUSKEY, Jill J. Production contracts as a means of vertical coordination with application to the wheat industry. Journal of Food Distribution Research, v. 31, n. 1, p. 215-224, March 2000.

ZIMATORE, Attilio. La tipizzazione dei contratti agrari. Il modello dell'enfiteusi. Torino: Edizioni QC, 1988.

ZUURBIER, Peter; TRIENEKENS, J. H. Introduction. In: Trienekens, J. H.; Zuurbier, P. (Eds.). Chain management in agribusiness and the food industry.. Wageningen: Wageningen Pers, 2000.

ZYLBERSZTAJN, Decio. Papel dos contratos na coordenação agro-industrial: um olhar além dos mercados. Revista Economia Rural, Rio de Janeiro, v. 43, n. 3, p. 385-420, jul.-set. 2005. 
Kassia Watanabe

Assistant Professor at Federal University of Recôncavo dA Bahia, Center of Agricultural, EnVIRONMENTAL AND

Biological SCIENCE.

wtkassialaufrb.edu.br

Nunziata Stefania Paiva Judge of LaW at GoIÁs COURT OF JUSTICE - JudicIAL DISTRICT of CORumbaíba.

mag.nsvpaivalayahoo.com.br

Ana Elisa Bressan Smith Lourenzani Assistant Professor at São Paulo State University (UNESP), SCHOOL OF SCIENCES ANd ENGINEERING, TUPÃ. 